This item was submitted to Loughborough's Research Repository by the author.

Items in Figshare are protected by copyright, with all rights reserved, unless otherwise indicated.

\title{
A theoretically grounded model to reduce the risk of knowledge loss in organisations: an energy company evaluation
}

PLEASE CITE THE PUBLISHED VERSION

http://dx.doi.org/10.1002/kpm.1502

PUBLISHER

(c) Wiley

VERSION

AM (Accepted Manuscript)

\section{PUBLISHER STATEMENT}

This work is made available according to the conditions of the Creative Commons Attribution-NonCommercialNoDerivatives 4.0 International (CC BY-NC-ND 4.0) licence. Full details of this licence are available at: https://creativecommons.org/licenses/by-nc-nd/4.0/

\section{LICENCE}

CC BY-NC-ND 4.0

\section{REPOSITORY RECORD}

Parboteeah, Paul, Thomas Jackson, and Nicola Wilkinson. 2019. "A Theoretically Grounded Model to Reduce the Risk of Knowledge Loss in Organisations: An Energy Company Evaluation”. figshare. https://hdl.handle.net/2134/23139. 


\title{
A Theoretically Grounded Model to Reduce the Risk of Knowledge Loss in Organisations: An Energy Company Evaluation
}

\begin{abstract}
The aim of the research described in this paper was to determine the relationship between knowledge sharing and knowledge loss through the development of a conceptual model of the factors affecting knowledge sharing and a conceptual toolkit which can be used by managers as an analysis tool. A theoretical, constructive approach was taken to the research through the use of a theory-building methodology to create a conceptual model of factors affecting knowledge sharing in organisations. Empirical research was carried out in the form of a case study, at an energy infrastructure organisation in the UK through questionnaires and formal interviews to validate the model. A revised conceptual model of factors affecting knowledge sharing was developed and evaluated, further improving the model. The empirical research resulted in the validation of past literature and created additional elements to the model. The main limitation is that only one industry case study was used for empirical validation. This was due to the limited timeframe of the research that suggests that further research should involve multiple case studies, covering a wide variety of industries. The model of factors affecting knowledge sharing allows managers to analyse their knowledge management strategies and offer suggestions of ways to reduce any risk of knowledge loss. There is a lack of conceptual models based on knowledge loss and this paper aims to solve this issue. This will be useful to businesses, helping them to improve their knowledge management initiatives, retain knowledge and gain competitive advantage over competitors.
\end{abstract}

Keywords Evaluation, Framework, Knowledge Management, Knowledge Loss, Learning Organisation, Model Creation

Sequitur

\section{Introduction}

The importance of Knowledge Management (KM) has increased dramatically since the 1980s and awareness is increasing of the value of intangible assets (e.g. Kakabadse, 2001). This is making the effective management of knowledge in organisations an important and even decisive competitive factor” (Hanisch et al., 2009, p.149). Today, businesses develop a KM strategy to "ensure that the alignment of organizational process, culture, and the KM-related information technology deployment produce effective knowledge creation, sharing, and utilization" (Davis et al., 2008, p.235). It is up to a manager to utilise the knowledge from an employee's head but a risk can be identified when an employee leaves, taking all knowledge with them. Preparation and processes should be put in place as part of a KM strategy to ensure the knowledge remains in the team.The aim of this paper is to create a model of factors affecting knowledge loss (KL) in organisations. The research follows the first 4 steps of Dubin's (1978) eight-step model creation methodology. The research in this paper presents a low/middle management framework that will aid managers prevent knowledge loss.

This paper begins by providing the research design that was used to create the knowledge sharing (KS) and knowledge loss model. Section 3 reviews the literature and defines the factors (units) that contribute to either effective knowledge sharing or knowledge loss and completes the theoretical stages of the model creation methodology. Section 4 conducts the empirical stage of the research, completing the model creation process. The paper concludes 
by discussing the model, its contribution to the literature and its implications for managing knowledge loss in organisations.

\section{Research Design}

The purpose of this research was to investigate the relationship between KS techniques and $\mathrm{KL}$, to develop a conceptual model based on past literature, and to test the model in a real-life organisation to highlight KL risks regarding KS behaviours. This section describes and justifies the research strategies and approaches used for this research. Dubin's model creation theory (Dubin,1978) was used to create the model identifying the risks to knowledge loss in organisations. Dubin's method consists of a two-part, eight-step theory building method (Figure 1) and aligns with a constructive research approach. The first part represents the structural components and the second part is the process of empirical research/validation (Ardichvilli et al., 2003). This paper will follow part 1 of the process to create the model, switching to Shinkfield and Stufflebeam's (1985) approach to to evaluate the model.

\section{[Figure 1 here]}

Evaluation is "the process of determining the merit, worth and value of things (Scriven 1991, p.1) and has three main uses: improvement, accountability and enlightenment (Shinkfield \& Stufflebeam 1985, p.7). Evaluation can be either formal or informal with Formal evaluation being "called for when there is a need to inform critically important decisions, especially ones that will affect many people, [...] or pose substantial risk" (Shinkfield \& Stufflebeam 2007, p.28). As informal evaluation "lacks systematic procedures and formally collected evidence” (Sanders et al 1997, p.7), formal evaluation was more suitable for this research.

Formal evaluation can either be formative or summative (Shinkfield \& Stufflebeam 2007). Formative evaluation aims to provide feedback for improvement and "the emphasis is on identifying the strengths and weaknesses of a programme" (Clarke 1999 p.7) whereas summative evaluation judges the merit and worth and the extent to which the desired goals have been attained (Patton 1994, p.312). This research uses formative evaluation as the strengths and weaknesses are to be assessed within the model. Patterson's 1986 evaluation criteria, cited in Holton \& Lowe (2007, p.313), was used for this research as it the empirical stage. It consists of eight criteria: importance, precision and clarity, parsimony, comprehensiveness, operationally, empirical validity, fruitfulness and practicality.

\section{Theoretical Background, Model Creation and Toolkit Development}

\subsection{Identification and Definition of the Units}

Units are "things out of which the theory is built" (Dubin 1976, p.26). Dubin created 5 classes of units: enumerative, associative, relational, statistical and summative and from a review of the literature, the following units were identified:

\section{Workspace Design}

The traditional style of individual workspaces is old but is still seen in organisations today. They tend to feature cubicles or offices for individual work, and often "hard to book" conference rooms for meetings (Richardson, 2011). In the 1990s it was recognised that 'alternative officing' was beneficial and Duffy (1997) created a theory of work patterns and space shown in Figure 2. Duffy created four work environments and suggested types of work incorporated into each one. From year 2000 the technology boom caused the workspace to adapt accordingly to a "digitally-driven type of workforce that is more flexible [...] and more 
geared to the needs of knowledge interactions" (Bichard et al., 2010, p.7). Interactive workspaces evolved "where devices of different natures are used in conjunction with each other" (Inkpen \& Wallace 2006, p.2) incorporating both a physical and information system environment. Thomas Allen researched elements of workspace design and found that personalization of the workspace can improve attitudes to work (Bartholomew 2005, p.42) highlighting the benefits of a good physical environment. However, even when that exists, $50 \%$ of office workers regularly emailed colleagues who were only 10 feet away (Bartholomew 2005),.

[Figure 2 here]

Knowledge Sharing Processes

The emphasis today is on people-centred techniques, understanding and meeting real business and knowledge needs and fitting in with organisational culture (Bartholomew, 2005). Begley (2004) argues that when interacting it is "often helpful to go back to the basics and get faceto-face" however, the constraints of time and budget makes it not always possible (Koning, 2010), making employees turn to KS tools such as email communication and teleconferencing. Many researchers and employees recognise the lack of richness in electronic communication is its most limiting aspect (Young, 1995) and Wittenberg, cited by Knowledge@Warton (2008) argues that teams that rely solely on electronic communication are less successful than those that understand the importance of face-to-face meetings. Thomas Davenport cited in Bichard et al. (2010, p.23) recognised the task relevance of IT systems, otherwise employees may spend up to $40 \%$ of their working day struggling with IT systems that are not properly integrated into their knowledge tasks.

It is essential for the meetings to be continuous and not just a one-off, as the more regularly they occur, the more effective they can be (Commonknowledge Associates, 2012). One approach to capture meeting knowledge is to conduct an After Action Review. This is a meeting between peers to "capture lessons learned immediately after an event, project, or an activity" (Faul and Camacho, 2004) and helps to build "collective operational knowledge" (Knoco Ltd, 2010). The criticism of these techniques is that they only focus on knowledge regarding an event, project or activity and Faul and Camacho fail to highlight a KS technique that encourages the sharing of day-to-day knowledge. In order for the business to see a longterm benefit, KS should be a routine activity and should not only occur after an event or problem.

Knowledge Portals

The Enterprise Knowledge Portal (EKP) was created as "the intersection between knowledge management and the enterprise portal" (Collins 2003, p.xi). These encourage greater sharing of explicit knowledge (Viney, 2006) and provide companies with a rich and complex shared information workspace (Belbaly et al., 2004). Knowledge portals allow KS between organisational levels but only for codified knowledge. This is why, additional to an EKP, team level knowledge portals are necessary to enable employees to have a personalised experience, enabling them to gain and share knowledge relevant to their everyday projects. "The emphasis today is on people-centred techniques, understanding and meeting real business and knowledge needs, and fitting in with organisational culture. IT is invaluable, but it is a supporting actor, not a star” (Bartholomew, 2005).

\section{$\underline{\text { Team Size }}$}


The number of employees reporting into a manager can determine the KS tools and techniques adopted. The website Team Building (2009) suggests that the ideal team size to achieve collaboration and co-operation is either five or six, and research shows that if the number of employees "goes above 9, communication tends to become centralized because members do not have adequate opportunity to speak to each other" (Matrix Teams, 2010). As the team increases in size, sub-groups can emerge due to the "degree of overlap across multiple demographic characteristics among a subset of team members" (Gibson \& Vermeulen 2003, p.202). These can positively affect the team by dividing the workload appropriately, however, when formed naturally they can discourage KS between the subsets and the whole team.

Having a mixture of skill levels within a team can prohibit communication and transition of skills between members. This represents the biggest issue in technical teams, as high-level qualifications and technical abilities are required to carry out the roles. The importance of KS increases when a team contains experts as the techniques of shadowing and mentoring less experienced employees can be utilised in order to share and maintain knowledge within the team (Rainmaker Group, 2012).

Team meetings are a common KS technique and "are arranged at a regular time and of a regular length each week or two” (Young 1995, p.25). Since early 2005 Communities of Practice (CoPs) "have emerged as one of the most researched and widely praised techniques for knowledge sharing” (Bartholomew 2005, p.15). The Institute for Research on Learning, cited in Liebowitz (2000), states a community must have similar value and lifestyles; however Jashapara (2004) states that the group should be self-selecting. Retna \& Ng (2011, p.42) suggests common interests and activities bring the community together. Therefore, Jashapara's concept of self-selection should take into consideration the individual's interest in sharing knowledge for that particular CoP.

Table 1 identifies the units identified so far.

[Table 1 here]

\subsection{Laws of Interaction between Units}

The next step in Dubin's method is identifying the law of interaction. A law of interaction determines how changes in one or more units affect the remaining units (Dubin, 1978). This research proposes one law: that in order to increase team based knowledge sharing, teams should have five or six members, a range of communication tools, and support collaborative workspaces.

\subsection{Theory Boundaries}

Dubin (1978) describes the boundaries as the domain over which the theory will apply and for this model the boundary is the learning organisation. A learning organisation is one that promotes learning among its employees (Evans, 1998) and therefore enables organisations to gain a large resource based advantage. The learning organisation has moved from defining interrelationships within a business to Huber (1991) highlighting that an entity successfully learns through processing information to change its range of potential behaviours. A decade later, Sanchez (2001), states that Organisational Learning aims to generate, disseminate, and apply knowledge within an organisation. These two statements are different as Huber bases OL on the process of information whereby Sanchez acknowledges knowledge for Organisational Learning. Evans (1998, p.201) states that "an LO is one that promotes 
learning among its employees - but, more importantly, is an organisation that itself learns from that learning" whereas Matlay (1997, p.4) cited in Matlay (2000) states "knowledge emerging from collective learning is much more complete and is usually recorded formally for corporate access and benefit”. Matlay highlights collective learning, highlighting the importance of KS in teams, however Evans suggests that an organisation can learn through its employees learning individually.

\subsection{Theory's System States}

System states is "a state in which all the units of the system take on characteristic values that have persistence through time" (Ardichvilli et al., 2003), thereby giving the whole system a distinctive condition (Dubin, 1978). There are two systems states for the model of factors affecting knowledge sharing:

Increasing knowledge sharing - This term was chosen because during this system state the manager is encouraging knowledge sharing within their team by undertaking the activities in Law 1.

Discouraging knowledge sharing - This term was chosen to reflect that during this system state the manager is discouraging knowledge sharing within their team by having an individual or corporate level focus .

\subsection{Initial Model of Factors Affecting Knowledge Sharing}

After following stages one through four, the conceptual model of factors affecting knowledge sharing was be developed (Figure 3). The left side of the model describes factors that encourage knowledge sharing and the right side describes factors discouraging knowledge sharing. The axis is tipped according to which factors exist on either side. If more factors exist on the left hand side then this shows knowledge sharing is encouraged, resulting in a reduced risk of knowledge loss. If more factors exist on the right side, knowledge sharing is discouraged and knowledge loss is a risk. In a state of equilibrium, when an equal number of factors exist on both sides, then the manager has created a situation whereby efforts to encourage knowledge sharing are cancelled out by factors supporting knowledge loss. Surrounding the entire model is the boundary of a learning organisation.

[Figure 3 here]

\subsection{Toolkit Development}

A toolkit was then created to provide a method of applying the model to organisations. The toolkit is an in-depth analysis of the model that has the primary aim of aiding managers in analysing potential risks within their team, based on KS practices and behaviours. Each element of the conceptual model was incorporated into the toolkit highlighting areas of risk that are perhaps missed on a day-to-day basis. A breakdown of each limitation within the toolkit is shown in Table 2. There is an indication scale of red, amber, and green within the toolkit. Red indicating potential high risk of knowledge loss, amber indicating some risk involved and green indicating there is low risk of knowledge loss occurring. The toolkit contains weightings for each response linking the responses back to the model of factors affecting knowledge sharing, allowing a manager to analyse their state of KS behaviours.

[Table 2 here]

\section{Evaluation}


A case study was used to test the conceptual model and toolkit as it provides "richness of data that can be obtained by multiple means when researchers restrict themselves to a single situation" (Cornford \& Smithson 2006, p.72). The case study chosen was an energy infrastructure company in the UK. Questionnaires and interviews were used and of 126 questionnaires distributed, 53 were returned, giving a $42 \%$ response rate. The questionnaire was distributed using an online questionnaire tool, and piloted beforehand to check no mistakes or biases were present. Open-ended interviews, between the researcher and selected managers, were also used as this approach enables "a researcher to explore casual relationships directly" (Cornford \& Smithson 2006, p.70) and also give the opportunity to explore the meaning and the conceptual dimensions of key terms in the model.

\subsection{Team Size}

Responses to questions on team size, shown in Figure 4, highlighted the large majority (72\%) thought that a medium sized team would benefit from two-way communication. Only $8 \%$ of respondents said a large team would benefit KS, which corresponds with the team sizes in the case study as only $6 \%$ had a team larger than 8 employees, therefore experience of $\mathrm{KS}$ in large teams is low. The knowledge teaching and learning responses showed that again the medium sized team were beneficial as $62 \%$ of the respondents agreed. A larger percentage, $24 \%$, stated that a large team would benefit from knowledge teaching and learning compared to a large team KS suggesting that learning and training is conducted in larger groups within the case study.

\subsection{Average Age}

Respondents were asked their expected retirement age range and the results show that the majority stated either 51-60 years or 61-70 years, covering $89 \%$ of the responses.

\section{[Figure 4 here]}

The researcher questioned job-searching activities and the results show that it is the younger age ranges, 21-30 and 31-40, that occasionally and regularly look for job opportunities (Shown in Figure 5). However, the younger age ranges also score high on the responses of never looking for internal jobs. This could be due to job role or individual factors. One respondent stated that "I like security in my role however changes in management or management attitudes will be a driver for me moving and looking for another role." The pattern that the younger age ranges more commonly look for job roles exists also in the external results, however, there was a significant higher number of 'Never' responses within all the age ranges for the external job searching results.

\section{[Figure 5 here]}

\subsection{Average Skill Level}

Comparing the job-searching activities results and the skill level responses, found a high majority of Level 7-8 employees (58\%) occasionally look for job roles externally. One respondent stated they do so "to compare market value and to see what other organisations are doing”. 5\% of Level 7-8 employees only looked as a result of displacement/redundancy and $37 \%$ of respondents reported they never looked at other external opportunities. Compared to the lower skill levels, the level 7-8 has the most respondents who regularly look for internal job opportunities. During the interviews two issues arose which had not been considered by the original model: employee competencies and the number of permanent staff. 
Six interviewees commented upon the need for "sharing knowledge across specialities" and "cross fertilisation of ideas and perspectives", with one engineer recognising the risk of a team member with specialised knowledge leaving the team. This is coupled with the risk of knowledge loss when using a large number of temporary or contract staff. As one interviewee revealed: "when a contractor did the work, in order to secure that knowledge we offered him a permanent place in the company [...] because it had gone beyond the capability of anyone else in the team”. In order to prevent such knowledge loss, several interviewees recommended not using contractors for sustained periods of time such that they become irreplaceable.

\subsection{Knowledge Sharing Tools and Techniques}

The two most common KS tools, with 93\% of respondents using them, were 'general team meetings' and 'email communication'. The less used tools were peer-assist meeting (34\%) and online messaging and mobile text or photo messaging only scores 39\% each. An 'other' option was given which produced: team away days, annual conferences, breakfast meetings, inclusion and diversity groups, computer based training packages and on the job training. Questions 2 and 3 aimed to analyse which common KS techniques were found to be most useful for KS and for teaching and learning. The results, in Table 3, show high similarity between both knowledge activities.

\section{[Table 3 here]}

The mode statistic for regularity of team meetings was 'Fortnightly'. If the meetings occurred less regularly respondents highlighted that these were less beneficial (Figure 6). One respondent who has team meetings less than once a month commented "I would prefer fortnightly team meetings to improve team moral, brain storming sessions, open discussions etc". Question 6 and 7 showed that $75 \%$ of respondents stated that verbal communication was more useful than documentation. A respondent stated that they "get bored of reading on computer and flit over online presentations", highlighting a disadvantage of using IT-centred KS techniques. However, 82\% stated that they document information "occasionally" to "all the time”. The results are shown in Figure 7.

\section{[Figure 6 here]}

[Figure 7 here]

\subsection{Workspace Design}

Questions were also asked to determine what type of working environment existed and whether respondents thought that environment was suitable for KS or not. 65\% of respondents stated that they worked within a 'Club' environment and 86\% of them either agreed or strongly agreed that the club environment was suitable for KS. The results shown in Figure 8 highlight that it is only the 'Hive' and 'Cell' environments that respondents thought not to be suitable for KS. The respondents were also asked to rate their agreement with statements regarding their workspace. The statement, "I regularly email colleagues who are sat within a few metres from my desk" had a variety of agreement levels, therefore suggesting other factors affect the decision of KS tools used. The statement "I can easily talk to both adjacent colleagues and people passing by my desk" had results showing that $90 \%$ of respondents either strongly agreed or agreed. This tells us that the case study department is open plan and a ‘club’ design. 
The statement "My manager allows personalisation of the workplace" showed the majority of respondents had permission from their manager to personalise their workspace, with the mode statistic being 'Agree'. However, 21\% of respondents answered neutral therefore suggesting that some constraint may be involved with personalisation. The responses to the statement "I feel that personalisation of work areas can positively affect motivation levels of employees and change attitudes to work" show a strong agree response rate and managers should consider this as a motivational tool.

\section{[Figure 8 here]}

[Figure 9 here]

\subsection{Knowledge Portals}

More than three-quarters of respondents (77\%) stated that their team has its own intranet site which shows that this knowledge sharing tool is commonly used within the case study. $66 \%$ of the respondents felt that an intranet site aided them in their day-to-day work, however, $12 \%$ stated that they never used the intranet site suggesting other tools are also used. Figure 10 shows the breakdown of the activities the intranet site is used for and their usefulness ranking. The most frequent reason, with 45\% voting it first, was Content Management.

\section{[Figure 10 here]}

\section{Model and Toolkit Refinement}

For the final step in Stage 3 for this study, the results were analysed and both the model and toolkit were refined. The results verified the elements within the model of factors affecting KS. The interviews gave more depth into this research and invaluable answers from interviewees caused the researcher to refine the model, shown in Figure 11. The model gained additional factors, placed equally on either side of the model due to their comparison traits. Table 4 outlines the new factors along with the interviewee quotations justifying their addition to the model.

\section{[Figure 11 here]}

[Table 4 here]

One interviewee stated that "the toolkit would be useful to view and use as a software programme or excel document", therefore the researcher converted the refined toolkit into MS Excel in preparation for re-testing. In MS Excel, the toolkit contained 4 tabs, each containing elements of the toolkit (Instructions, Toolkit, Risk Summary, Knowledge Sharing Analysis). The Instructions tab gave the manager an introduction to the toolkit and explained each stage of the file. The second tab in the MS Excel file contained the toolkit. The manager inserts their answers and then using the drop-down menu selects one of the predefined options.

Once a manager has answered each of the toolkit questions, the next tab titled Risk Summary (Figure 12), is automatically populated. The summary highlights to the manager which knowledge sharing aspects are at which level of risk. The final tab titled Knowledge Sharing Analysis links the toolkit back to the conceptual model of factors affecting knowledge sharing. The graph is automatically populated through the excel formulas, determined by the model weightings, and shows a team's state of knowledge sharing behaviours. A desired 
result is for the factors increasing knowledge sharing bar to be taller than the Factors discouraging knowledge sharing.

[Figure 12 here]

\section{Discussion and Implications for Managers and Practitioners}

Many respondents claimed to work within a 'Club' environment and a large majority of them agreed that it is suitable for KS. This confirms Duffy's work patterns and space (1997) defining that club environments create knowledge work. As both Hive and Cell environments were found to be unsuitable for KS, and Duffy states they contain low interaction levels, this provides evidence to support the model element of 'Individualistic Workspace' to be discouraging KS. The majority of respondents were able to personalise their workspace and many agreed that this strategy affects motivation levels and attitudes towards work. Those respondents who stated to be within a club environment admitted to emailing colleagues sat just a few metres away from them, confirming that Allen's research finding that $50 \%$ of office workers regularly email colleagues only 10 feet away.

Team meetings were shown to occur fortnightly for most respondents, which supported Young's (1995) suggestions that they should occur each week or two. However, other factors are considered such as manager preference and time availability. A respondent who has monthly team meetings stated that there is "no time for more meetings" and another respondent who only has team meetings when required commented "the manager obviously doesn't believe such meetings are important”. Three-quarters of respondents preferred faceto-face communication to documentation, which supports the model element of 'Peoplecentred Tools \& Techniques' encouraging KS.Many respondents stated they document information "occasionally" to "all the time". This suggests that the KM strategies within the case study incorporate both types of communication but still with a preference of face-to-face. One respondent stated they document all the time "because sometimes written information can be misconstrued or misinterpreted. I actually prefer to combine the two. Use documentation but take the person through it”. This statement supports Serrat's (2009) suggestions that both interpersonal contact and access to documentation is best for KS.

The results showed that over three-quarters of respondents had access to a team specific intranet site/knowledge portal. Content Management was the main reason why employees utilised the site, which supports Belbaly et al. (2004) stating that it's a shared information workspace. Many viewed the site as useful and used it daily or weekly, which supports the model element of 'Team Knowledge Portal' being a factor that encourages KS. Those that did not have a site (two-thirds of respondents), did not have a knowledge portal in their team therefore they had not been exposed to the possible benefits of such a site and immediately doubt its usefulness.

The majority of respondents agreed that a medium sized team containing four to seven members best encouraged KS. This reinforces the suggestions from the website Team Building (2009) where an ideal size for collaboration and co-operation was said to be five or six people. A large team was shown to be least beneficial for KS, therefore validating the model element of 'Large size of Team' being associated with discouraging KS. However, a low number of respondents had a large team of $8+$ members therefore respondents may have agreed with medium team size due to it being the norm. Teaching and learning was also 
suggested to be more useful in a medium sized team, however, a larger majority stated that a large team is useful suggesting that the company encourages learning situations to be in large groups. This agrees with the website Matrix Teams (2010) who recognise that a group of 9+ people do not have adequate opportunities to communicate, as learning within business is commonly through training, communication is one-way, therefore the need to communicate individually does not exist.

A large majority of respondents had an expected retirement age either between 51-60 years or 61-70 years. The accuracy of responses can be debated due to the use of future tense within the question. An employee cannot plan their retirement age due to other factors being considered such as the economy, family and job security. The majority of respondents who regularly searched for job roles both internally and externally were of the lower age ranges. This proved that the research carried out by Hyphen finding that younger age ranges like to change jobs more often (Recruiter, 2011) existed in this research. Most employees are between $31-40$ years and $85 \%$ are 50 years or below, therefore contradicting the literature stating that the Utilities industry traditionally contains an ageing workforce.The literature states that the younger workers prefer to change job roles more often, and perhaps highlighting an immediate risk of KL by having a younger workforce.

Over half of respondents at Level 7-8 admitted to occasionally looking for job roles externally. One respondent stated, "I don't think the organisation values its experienced employees anymore you are an asset to be used and abused. I feel other companies value their staff". This suggests that motivation and company culture can be factors affecting an employee's decision to leave a company.Headhunting is also a factor to consider as one respondent stated they are contacted a lot by agencies, therefore showing the vulnerability of a higher skilled employee. There is a spread of both 'occasionally' and 'never' when looking for internal jobs for the higher skilled employees, but they still look for more jobs compared to the lower skilled employees. This reinforces the suggestions made by the website Rainmaker group (2012) highlighting to utilise the experts in the team to transfer knowledge to others before leaving.

Throughout the analysis, evidence was shown that supported past literature on each factor within the conceptual model. A workspace was shown to be a considerable factor to affect $\mathrm{KS}$, as the level of physical interaction available determines communication methods. Faceto-face communication was favoured over tools using IT systems however it was found that a combination of the two could prove more valuable when KS.One specific IT system, knowledge portal, was proved to be utilised regularly therefore justifying it being a separate element encouraging KS in the conceptual model. The results proved that KS is more useful within a smaller team and larger teams are associated with learning and one-way communication. Overall, all the factors discussed did have an effect upon KS, whether they encouraged or discouraged it. It is upon the manager to implement the correct tools, techniques and create a KS environment in order to reduce the risk of KL occurring.

\section{Conclusion}

The aim of this research was to analyse the relationship between knowledge sharing and knowledge loss at the team level. There is a large amount of literature around both topics, and a gap in the research was found regarding a tool for lower-level managers to analyse their risk of knowledge loss. After an extensive literature review, a model of factors affecting knowledge sharing was developed following Dubin's theory-building method. Primary research was then conducted using an online questionnaire and formal interviews containing 
questions regarding which knowledge sharing tools were utilised. A second questionnaire pilot was undertaken to ensure common knowledge sharing tools were given as choices in the questions. The researcher compared the responses of other sections of data, giving an indication of commonality and preference of techniques whilst highlighted other factors taken into consideration. Graphs were produced showing preferences and showed that both verbal communication and documentation (IT Systems) were incorporated in KM strategies.

The KM techniques within this case study highlighted successful attempts within the teams and throughout the organisation to share knowledge. However, it was said that communication would always be an issue due to the size of the company and the regularity of communication. This means the communication strategies chosen are a defining factor for effectiveness. Finally, this study used Patterson's (1986) criteria to evaluate the model of factors affecting knowledge sharing.

\subsection{Limitations}

Due to the limited scale of this research, there are a number of limitations. The researcher had to use convenience sampling for the formal interviewees, and a larger sample size would have provided greater analysis and feedback of the model. When using Dubin's theorybuilding method, only one law of interaction was studied. More interactions could have been investigated between the different units of theory, adding further depth.. Due to the lack of theoretical work surrounding this research, it was not possible to rely on or obtain guidance from any other similar study. This could have added to the reliability and validity of the research. Having been the first to create a toolkit to analyse areas of knowledge loss based upon knowledge sharing behaviours, it stands alone as theoretical work to be developed further.

\subsection{Further Research}

The research was unable to carry out stage 2 of Dubin's theory-building method, suggesting further research of past literature could be done in order to establish suitable empirical indicators and hypotheses to test. As the research was only carried out within one commercial department of a global company, it would be appropriate to carry out further research and empirical testing, firstly amongst other departments within this case study company, perhaps those containing engineering roles, and then to carry out empirical testing of the tools within other industries other than the utilities industry.

\section{References}

After Action Reviews, 1997. <http://www.nwlink.com/ donclark/leader/leadaar.html>, [accessed 26.02.12].

Amble, B., 2007. Employers in denial over ageing workforce. <http://www.managementissues.com/2007/3/19/research/employers-in-denial-over-aging-workforce.asp $>$, [accessed 26.02.12]

Ardichvilli, A., Cardozo, R. \& Ray, S., 2003. A theory of entrepreneurial opportunity identification and development. Journal of Business Venturing, 18(1), 105-123.

Argyris, C. \& Schon, D., 2011. Value Based Management: Organisational Learning. $<$ http://www.valuebasedmanagement.net/methods_organizational_learning.htmll>, [accessed 31.10.11].

Bartholomew, D., 2005. Sharing Knowledge. $<$ http://www.knowledgeboard.com/download/2520/SharingKnowledge1.pdf $>$, [accessed 14.10.11]. 
Begley, K. A., 2004. Face to Face Communication: making human connections in a technology-driven world. <http://www.axzopress.com/downloads/pdf/1560526998pv.pdf>, [accessed 28.02.12].

Belbaly, N. A., Benbya, H. \& Passiante, G., 2004. Corporate Portal: a tool for knowledge management synchronization. International Journal of Information Management, 24(1), 201220.

Bernard, A \& Xu, Y., 2011. Quantifying the value of knowledge within the context of product development. Knowledge-Based Systems. 24(1), 166-175.

Bichard, J.A., Erlich, A, \& Myerson, J., 2010. New demographics, new workspace: office design for the changing workforce [online]. Gower.

<http://www.dawsonera.com/depp/reader/protected/external/AbstractView/S9780754692126 $>$, [accessed 26.03.12].

Bontis, N. \& Choo, C. W., 2002. The Strategic Management of Intellectual Capital and Organizational Knowledge. United States of America: Oxford.

Burrell, G \& Morgan, G., 1979. Sociological paradigms and Organisational analysis. London: Heinemann.

Butterfield, E. C., Lachman, J. L. \& Lachman, R., 1979. Cognitive Psychology and Information Processing: An Introduction [online]. Lawrence Erlbaum Associates Publishers. Catano, V. M et al., 2010. Recruitment and Selection in Canada [online]. Nelson. Clarke, A., 1999. Evaluation Research: An introduction to principles, methods and practice [onlne]. Sage.

Collins, H., 2003. Enterprise Knowledge Portals. United States of America: Amacom. Commonknowledge Associates, 2012.

$<$ http://www.commonknowledge.org/userimages/aar_guidelines.pdf $>$, [accessed 26.02.12]. Cope, M., 2000. Know your value? Manage your knowledge and make it pay. Great Britain: Pearson.

Cornford, T. \& Smithson, S. 2006. Project Research in Information Systems: A Student's Guide. China: Palgrave Macmillan.

Davis, J. G. et al., 2008. Effects of knowledge management strategy on organizational performance: a complementarity theory-based approach. Knowledge Management and Organizational Learning [online], 36(2), 235-251.

<http://www.sciencedirect.com/science/article/pii/S0305048306000983>, [accessed 27.03.12].

Desouza, K, C. \& Paquette, S., 2011. Knowledge Management: an introduction. USA: NealSchuman Publishers.

Du Toit, A. S. A \& Mearns, M. A., 2008. Knowledge Auidt: tools of the trade transmitted to tools for tradition. International Journal of Information Management, 28(3), 61-167. Egan, T. M. \& Upton, M. G., 2010. Three approaches to multilevel theory building. Human Resource Development Review, 9(4), 333-356.

Evans, S., 1998. Revisiting the learning organisation. Work Study, 47(6), 201-203.

Faul, M, \&Camacho, K., 2004. Knowledge Sharing Toolkit: An evolving collection of practical knowledge sharing techniques.

Firestone, J, M., 2003. Enterprise Information Portals and Knowledge Management. United States of America: Butterworth-Heinemann.

Frank, B., [n.d.] Five Tips to Reduce Knowledge Loss.

$<$ http://www.providersedge.com/docs/km_articles/Five_Tips_to_Reduce_Knowledge_Loss.p $\mathrm{df}>$, [accessed 03.01.12].

Fuller, S., 2002. Knowledge Management Foundations. United States of America:

Butterworth-Heinemann. 
Galliers, R. D., 1992. Information Systems Research: Issues, Methods and Practical Guidelines. Oxford: Blackwell.

Garcia, S. K., 2008. Toward a social network-based theory of large-group interventions [online]. ProQuest.

Gibson, C. \& Vermeulen, F., 2003. A Healthy Divide: Subgroups as a Stimulus for Team Learning Behaviour. Administrative Science Quarterly, 48(2).

Gillham, B., 2000a. Case Study Research Methods. London: Continuum.

Gillham, B., 2000b. Developing a Questionnaire. London: Continuum.

Goh, W. \& Yahya, S., 2002. Managing human resources toward achieving knowledge management. Journal of Knowledge Management, 6(5), 457-468.

Greenspan, S., et al, 2010. Uncovering cultural perceptions and barriers during knowledge audit. Journal of Knowledge Management, 14(1), 114-127.

Grinnell, R., 2008. Empirical Validity.

$<$ http://psychcentral.com/encyclopedia/2008/empirical-validity/>, [accessed 04.04.12].

Hanisch et al., 2009. Knowledge Management in Project Environments. Journal of

Knowledge Management, 13(4), 148-160.

Hansen, M. T., 2002. Knowledge Networks: Explaining Effective Knowledge Sharing in

Multiunit Companies. Organization Science, 13(3), 232-248.

Ho, S, K, M., 1999. Total Learning Organisation. The Learning Organization, 6(3), 116-120.

Holton, E. F. \& Lowe, J. S., 2007. Toward a General Research Process for Using Dubin's

Theory Building Model. Human Resource Development Review [online], 6(3), 297-320.

$<$ http://hrd.sagepub.com/content/6/3/297.full.pdf+html>, [accessed 03.03.12].

Iivari, J. 1991. A paradigmatic analysis of contemporary schools of IS development.

European Journal of Information Systems, 1(4), 249-272.

Insley, J., 2012. Retirement age is on the up., says ONS.

<http://www.guardian.co.uk/money/2012/feb/16/retirement-age-up-ons>, [accessed 28.02.12].

Jackson, T. W., 2011. Modelling the factors of Information Overload.

$<$ http://www.DrThomasJackson.com/io/io.pdf $>$, [accessed 26.02.12].

Jantunen, A., et al, 2011. Value of Knowledge - Technology strategies in different

knowledge regimes. International Journal of Production Economics, 131(1), 273-281.

Jashapara, A., 2004. Knowledge Management: an integrated approach. Britain: Pearson.

Kakabadse, N., Kouzmin, A. and Kakabadse, A. (2001), From tacit knowledge to knowledge management: leveraging invisible assets. Knowledge and Process Management, 8: 137-154. doi: 10.1002/kpm.120

Kalton, G \& Moser, C. A., 1992. Survey Methods in Social Investigation. Great Britain: Gower.

Kappel, K., 2010. Expressivism about knowledge and the value of knowledge. Acta

Analytica-international Periodical for Philosophy in the Analytical Tr, 25(2), 175-194.

Kikoski, C, K \& Kikoski, J, F., 2004. The Inquiring Organisation Tacit Knowledge,

Conversion, and Knowledge Creation: Skills for $21^{\text {st }}$-Century Organizations. United States of

America: Praeger.

Knoco Ltd. 2010. After Action Review. <http://www.knoco.com/after-action-review.htm>, [accessed 28.02.12].

Knowledge@Warton, 2006.

$<$ http://knowledge.wharton.upenn.edu/article.cfm?articleid=1501>, [accessed 25.02.12].

Koning, L., 2010. When to use email, phone or face-to-face communication.

$<$ http://www.managementtrainee.co.uk/when-use-email-phone-facetoface-

communication.html $>$, [accessed 28.02.12].

Kvale, S., 2008. The SAGE Qualitative Research Kit: Doing Interviews. Wiltshire:Sage. 
Li, Y \& Wu, Y., 2008. Research on the Model of Knowledge Audit.

$<$ http://ieeexplore.ieee.org/stamp/stamp.jsp?tp=\&arnumber=4680856>, [accessed 26.03.12].

Liebowitz, J., 2000. Building Organizational Intelligence: A Knowledge Management Primer. United States of America: CRC Press.

Marr, B., 2005. Perspectives on Intellectual Capital. United States of America: Elsevier Butterworth-Heinemann.

Marsick, V. J \& Watkins, K. E., 1999. Dimensions of the Learning Organisation

Questionnaire. <http://www.partnersforlearning.com/questions2.asp>, [accessed 27.12.11].

Massingham, P., 2010. Knowledge risk management: a framework. Journal of Knowledge

Management, 14(3), 464-485.

Matlay, H., 2000. Organisational learning in small organisations. Education + Training, 42(4/5), 202-210.

Matrix Teams, 2010. <http://www.nwlink.com/ donclark/leader/leadtem2.html>, [accessed 25.02.12].

Muller-Prothmann, T., [n.d.]. Social network analysis: a practical method to improve knowledge sharing. <http://www.knowledge-

experts.com/files/kb_ebook02_social_network_analysis_knowledge_sharing.pdf $>$, [accessed 24.02.12].

Parboteeah, P. and Jackson. T.W. 2011. Expert evaluation study of an autopoietic model of knowledge. Journal of Knowledge Management, 15(4), 688-699.

Patton, M. Q., 1994. Developmental Evaluation. Evaluation Practice, 15(3), 311-319.

Rainmaker Group, 2012. The real cost of employee turnover.

$<$ http://www.therainmakergroupinc.com/employee-retention-articles/bid/80350/The-Real-

Costs-of-Employee-Turnover $>$, [accessed 26.02.12].

Recruiter, 2011. <http://www.recruiter.co.uk/young-workers-primed-for-job-

hopping/1011108.article>, [accessed 28.02.12].

Renzi, B., 2008. Trust in management and knowledge sharing: The mediating effects of fear and knowledge documentation. Knowledge Management and Organizational Learning, 36(2), 206-220.

Retna, K, S \& Ng, P, T., 2011. Communities of Practice: dynamics and success factors.

Leadership and Organization Development Journal, 32(1), 41-59.

Richardson, A., 2011. Inventing the Collaborative Workspace. In: HBR Blog Network

[online]. [viewed 25.02.12]. Available from:

http://blogs.hbr.org/cs/2011/11/inventing_the_collaborative_workspace.html

Riege, A., 2005. Three-dozen knowledge-sharing barriers managers must consider. Journal

of Knowledge Management, 9(3), 18-35.

Sanders, J. R., Fitzpatrick, J. L., \& Worthen, B. R., 1997. Program Evaluation: Alternative approaches and practical guidelines [online]. Addison Wesley Longman, Inc.

$<$ https://web.utk.edu/ cdavis80/EP521/readings/Worthen1.pdf >, [accessed 03.04.12].

Scriven, M.,1991. Evaluation Thesaurus [online]. Sage.

Serrat, O., 2008. Knowledge Solutions: Auditing Knowledge.

$<$ http://www.adb.org/Documents/Information/Knowledge-Solutions/Auditing-

Knowledge.pdf $>$, [accessed 01.11.11].

Serrat, O. 2009. Building a Learning Organization.

$<$ http://www.adb.org/Documents/Information/Knowledge-Solutions/Building-a-Learning-

Organization.pdf $>$, [accessed 27.02.12].

Shinkfield, A. J \& Stufflebeam, D. L., 1985. Systematic Evaluation. USA: Kluwer Academic

Publishers Group.

Shinkfield, A. J \& Stufflebeam, D. L., 2007. Evaluation theory, models and applications

[online]. Wiley. 
Song, S \& Teng, J. T. C., 2011. An exploratory examination of knowledge-sharing behaviours: solicited and voluntary. Journal of Knowledge Management, 15(1), 104-117. Team Building, 2009.

$<$ http://www.teambuildingportal.com/articles/systems/teamperformance-teamsize>, [accessed 25.02.12].

Viney, D., 2006. Intranet Portals - Collaboration through Team Rooms. $<$ http://www.sharepointhosts.com/intranet-portals.php>, [accessed 26.02.12].

Walsham, G. 1993. Interpreting Information Systems in Organizations. Chichester: Wiley. Young, D. P., 1995. The relationship between electronic and face-to-face communication and its implications for alternative workplace strategies. Facilities Journal, 13(6), 20-27. 
Table 1 Identification of Units

Workspaces

Tools and techniques

Knowledge portals

Team size 
Table 2 Initial toolkit elements

\begin{tabular}{|c|c|c|c|c|}
\hline No. & $\begin{array}{l}\text { Toolkit } \\
\text { Element }\end{array}$ & Limits & Weighting & Literature \\
\hline \multirow[t]{3}{*}{1} & \multirow{3}{*}{$\begin{array}{l}\text { Which of the } \\
\text { following best } \\
\text { describes your } \\
\text { team's } \\
\text { workplace? }\end{array}$} & Hive or Cell & Discouraging & $\begin{array}{l}\text { Hive and Cell designs both have low levels of } \\
\text { interaction involved, therefore discouraging } \\
\text { the behaviour of knowledge sharing (Duffy, } \\
\text { 1997). }\end{array}$ \\
\hline & & Den & Encouraging & $\begin{array}{l}\text { Den designs tend to focus on group processes } \\
\text { as the main work pattern but with a low level } \\
\text { of employee autonomy. }\end{array}$ \\
\hline & & Club & Encouraging & $\begin{array}{l}\text { Transactional knowledge work is the key } \\
\text { work pattern in a club environment and } \\
\text { encourages a high level of interaction among } \\
\text { employees. It enables a high level of } \\
\text { employee autonomy and still enables them to } \\
\text { gain recognition. }\end{array}$ \\
\hline \multirow[t]{3}{*}{2} & \multirow{3}{*}{$\begin{array}{l}\text { Do you conduct } \\
\text { regular team } \\
\text { meetings? }\end{array}$} & Yes & Encouraging & \multirow{3}{*}{$\begin{array}{l}\text { Regular staff meetings are the most common } \\
\text { and are often focused on a status report style, } \\
\text { arranged at a regular time and date (Young, } \\
\text { 1995). Meetings allow for expertise to be } \\
\text { shared and opinions to be expressed. }\end{array}$} \\
\hline & & $\begin{array}{l}\text { Only when } \\
\text { needed }\end{array}$ & Discouraging & \\
\hline & & No & Discouraging & \\
\hline \multirow[t]{3}{*}{3} & \multirow[t]{3}{*}{$\begin{array}{l}\text { Do you } \\
\text { regularly carry } \\
\text { out review } \\
\text { meetings/ after } \\
\text { action reviews? }\end{array}$} & Yes & Encouraging & $\begin{array}{l}\text { After action reviews are held at the end of a } \\
\text { project phase or event. They allow a team to } \\
\text { capture when happened and the lessons that } \\
\text { can be learnt and build collective organisation } \\
\text { knowledge (Knoco Ltd., 2010) }\end{array}$ \\
\hline & & $\begin{array}{l}\text { Only when } \\
\text { needed }\end{array}$ & Discouraging & $\begin{array}{l}\text { CommonKnowledge Associates (2012) argue } \\
\text { it is the discipline of the regularity of these } \\
\text { meetings that makes them effective. They } \\
\text { should become part of the way a team works. }\end{array}$ \\
\hline & & No & Discouraging & \\
\hline \multirow[t]{3}{*}{4} & \multirow{3}{*}{$\begin{array}{l}\text { Which methods } \\
\text { of } \\
\text { communication } \\
\text { do you } \\
\text { encourage } \\
\text { amongst your } \\
\text { team? }\end{array}$} & $\begin{array}{l}\text { IT based } \\
\text { (phone/ email) }\end{array}$ & Discouraging & $\begin{array}{l}\text { The most limiting aspect of electronic } \\
\text { communication is the lack of richness it } \\
\text { provides in terms of non-verbal } \\
\text { communication. }\end{array}$ \\
\hline & & Face-to-face & Encouraging & $\begin{array}{l}\text { For the best interaction, it is best to go back to } \\
\text { basics and get face-to-face because the best } \\
\text { communication usually happens when the } \\
\text { speaker and listener are in the same room } \\
\text { (Begely, 2004). }\end{array}$ \\
\hline & & Mixed approach & Encouraging & $\begin{array}{l}\text { The constraints of time and budget usually } \\
\text { mean it is not possible to always meet face-to- } \\
\text { face and it is important to use a combination } \\
\text { of methods to communicate (Koning, 2010). }\end{array}$ \\
\hline \multirow[t]{3}{*}{5} & \multirow[t]{3}{*}{$\begin{array}{l}\text { Does your team } \\
\text { have a Team } \\
\text { Intranet/ Portal } \\
\text { Site }\end{array}$} & Yes & Encouraging & $\begin{array}{l}\text { Structured and unstructured search } \\
\text { technologies are usually the core of strategies } \\
\text { to encourage greater sharing of explicit } \\
\text { knowledge (Viney, 2006). }\end{array}$ \\
\hline & & $\begin{array}{l}\text { Reliant on } \\
\text { corporate } \\
\text { intranet }\end{array}$ & Discouraging & $\begin{array}{l}\text { Corporate portals present the potential of } \\
\text { providing organisatoins with a rich and } \\
\text { complex shared information workspace, } \\
\text { however it is not optimised for employees day } \\
\text { to day use (Belably et al., 2004). }\end{array}$ \\
\hline & & No & Discouraging & \\
\hline \multirow[t]{2}{*}{6} & \multirow[t]{2}{*}{$\begin{array}{l}\text { How many team } \\
\text { employees } \\
\text { report into you? }\end{array}$} & 9+ employees & Discouraging & $\begin{array}{l}\text { If the number goes above nine, } \\
\text { communication tends to become centralised } \\
\text { (Matrix Teams, 2009). }\end{array}$ \\
\hline & & 6-8 employees & Discouraging & $\begin{array}{l}\text { Sub-group strength, defined as the degree of } \\
\text { overlap across multiple demographic }\end{array}$ \\
\hline
\end{tabular}




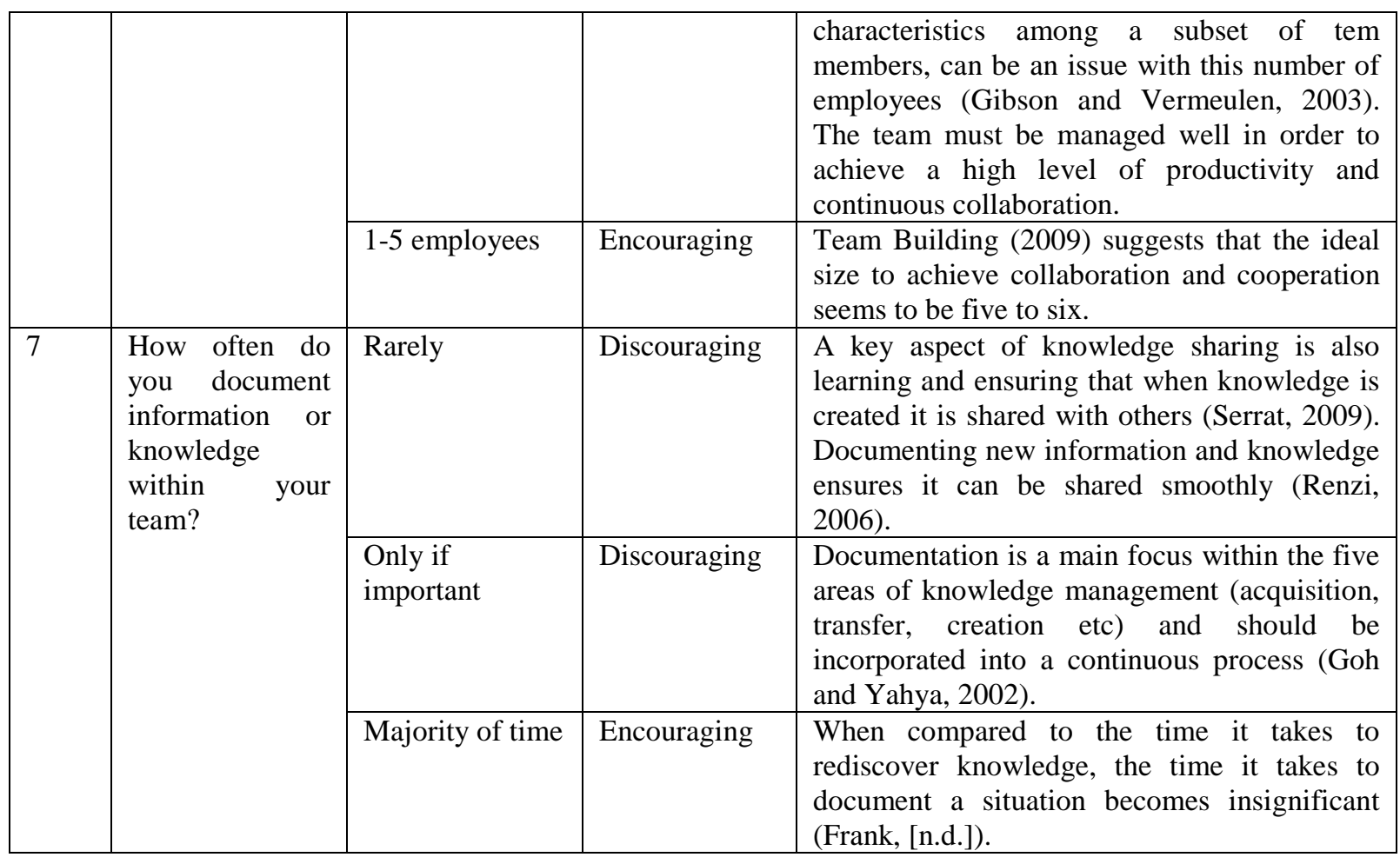


Table 3 Usefulness of Tools for KS and Teaching \& Learning

\begin{tabular}{|l|l|l|}
\hline $\begin{array}{l}\text { Usefulness } \\
\text { Score }\end{array}$ & Results for Knowledge Sharing & Results for Teaching \& Learning \\
\hline $\mathbf{1}^{\text {st }}$ & Team meetings/formal discussions & Team meetings/formal discussions \\
\hline $\mathbf{2}^{\text {nd }}$ & Review sessions/post-project meetings & Review sessions/post-project meetings \\
\hline $\mathbf{3}^{\text {rd }}$ & Informal Conversation & Informal Conversation \\
\hline $\mathbf{4}^{\text {th }}$ & $\begin{array}{l}\text { Online team intranet site \& TeamTalk } \\
\text { Meetings }\end{array}$ & Online team intranet site \\
\hline $\mathbf{5}^{\text {th }}$ & TeamTalk Meetings & TeamTalk Meetings \\
\hline $\mathbf{6}^{\text {th }}$ & Town Hall/Open Meetings & Town Hall/Open Meetings \\
\hline
\end{tabular}


Table 4 Additional toolkit elements

\begin{tabular}{|c|c|c|c|c|}
\hline No. & $\begin{array}{l}\text { Toolkit } \\
\text { Element }\end{array}$ & Limits & Weighting & Research Quotation \\
\hline \multirow[t]{3}{*}{8} & \multirow[t]{3}{*}{$\begin{array}{l}\text { Employee } \\
\text { Competencies }\end{array}$} & Diverse & Discouraging & \multirow{3}{*}{$\begin{array}{l}\text { "I am the only qualified engineer, so if I leave } \\
\text { then we have lost a lot of knowledge... I think } \\
\text { it's on our radar but it's not really a succession } \\
\text { plan we have in place." } \\
\text { "If you streamline processes to beyond your } \\
\text { team's capabilities, you'll actually lose the } \\
\text { ability." } \\
\text { "We've got specialism in quite a few areas } \\
\text { and as long as you share that knowledge freely } \\
\text { then I think it works quite well." }\end{array}$} \\
\hline & & Partial & Encouraging & \\
\hline & & Similar & Encouraging & \\
\hline \multirow[t]{3}{*}{9} & \multirow[t]{3}{*}{$\begin{array}{l}\text { Number of non- } \\
\text { permanent staff }\end{array}$} & $50 \%+$ & Encouraging & \multirow{3}{*}{$\begin{array}{l}\text { "He was a contractor when he did the work } \\
\text { and just to secure that knowledge we offered } \\
\text { him a permanent place in the company so that } \\
\text { we didn't lose that knowledge because it had } \\
\text { gone beyond the capability of anyone else in } \\
\text { the team." } \\
\text { "People who are essentially learning on the } \\
\text { job as contractors... a whole bunch of } \\
\text { relationship building knowledge, technology } \\
\text { and solution knowledge, vendor knowledge } \\
\text { and stakeholder knowledge, that experience } \\
\text { you can't document gets lost when that person } \\
\text { moves on. There is a big knowledge leakage } \\
\text { that we are trying to protect." }\end{array}$} \\
\hline & & $25-49 \%$ & Discouraging & \\
\hline & & $0-24 \%$ & Discouraging & \\
\hline \multirow[t]{3}{*}{10} & \multirow{3}{*}{$\begin{array}{l}\text { Level of } \\
\text { stakeholder } \\
\text { engagement }\end{array}$} & High & Encouraging & \multirow{3}{*}{$\begin{array}{l}\text { "Personnel changes within a supplier... } \\
\text { learning curve to go through about building } \\
\text { relationships and we also lost a lot of } \\
\text { knowledge there in terms of technical } \\
\text { experience on our products and requirements." }\end{array}$} \\
\hline & & Sometimes & Discouraging & \\
\hline & & Low & Discouraging & \\
\hline \multirow[t]{3}{*}{11} & \multirow[t]{3}{*}{$\begin{array}{l}\text { Team } \\
\text { motivation and } \\
\text { trust }\end{array}$} & Low & Discouraging & \multirow{3}{*}{$\begin{array}{l}\text { "Generally people like to be valued and } \\
\text { involved at a motivational level." } \\
\text { "My style as a manager is inclusive and I like } \\
\text { to run an involved team so that everyone has } \\
\text { got a flavour of what is going on, even at a } \\
\text { high level, and everyone knows who to talk } \\
\text { to." } \\
\text { "I agree that motivation can impact } \\
\text { knowledge sharing activities but it can also } \\
\text { work the other way as knowledge sharing can } \\
\text { increase the motivation and the rapport within } \\
\text { teams." }\end{array}$} \\
\hline & & Unsure & Discouraging & \\
\hline & & High & Encouraging & \\
\hline
\end{tabular}

